\title{
Remote Intervillous Thrombus
}

National Cancer Institute

\section{Source}

National Cancer Institute. Remote Intervillous Thrombus. NCI Thesaurus. Code

C117329.

A focus of maternal thrombus within the placental intervillous space, often with peripheral villous compression, which is at least 5-7 days in age. 